\title{
Pla(y)ceskabelse
}

- når børn og robotteknologi mødes

\section{Herdis Toft}

Lektor

Uddannelsesvidenskab, Institut for

Kulturvidenskaber, Syddansk Universitet.

\section{Rikke Toft Nørgaard}

Adjunkt, PhD

Center for Undervisningsudvikling og Digitale Medier, IKK, Aarhus Universitet.
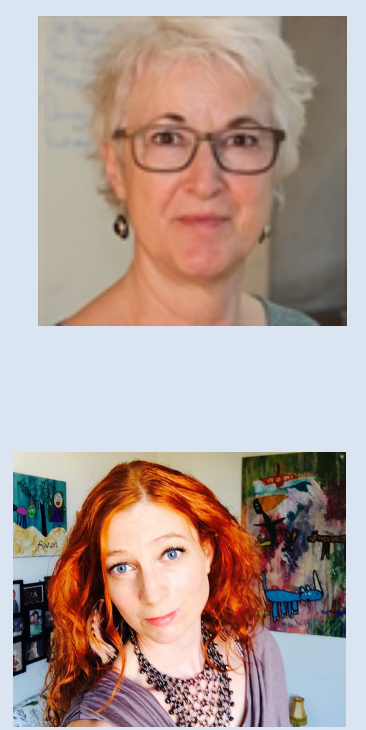


\section{Abstract}

Artiklen viser, hvordan et interdisciplinært ståsted mellem

konstruktionisme / pragmatisk designtænkning og nordisk legekulturteori bidrager med nye perspektiver på brug af modulær robotteknologi i børns institutionaliserede legekultur, herunder især på dannelsespotentialet $\mathrm{i}$ børns møde med robotteknologi. Gennem en analyse af feltobservationer af børnehavebørns leg med Modular Robotic Tiles vises, hvordan robotteknologi gennem leg kan lykkes med at transgredere fra velfærdsteknologi til en teknologi, børn leger og designer med. Kernebegreberne pla(y)ce-skabelse og transgression definerer dannelsespotentialet i leg anskuet som designvirksomhed. I artiklens interdisciplinære analysemodel sættes desuden modularitet, flytbarhed, idégenerering, problemløsning, åbenhed og tilblivelse - som kategorier for konkrete design- og læringspotentialer i legende børns interaktioner med robotteknologier - sammen med kategorier for konstruktions- og refleksionsspørgende handlinger, herunder det legekulturelle: "Hvad nu hvis...?" og det designtænkende: "Hvordan kan vi...?". Artiklen konkluderer, at mødet mellem legebørn og robotteknologi, konceptualiseret som pla(y)ceskabelse, kan fremme børns erobring af distribueret demokratisk dannelse.

\section{English abstract}

The article shows how an interdisciplinary perspective that combines constructionism / pragmatic design thinking and nordic theories for play culture contribute with new views on the use of modular robotics in children's play culture within institutions, specifically focusing on potentials for personal formation when children and robotics meet. Through analysis of fieldwork observations of children's play with Modular Robotic Tiles it is demonstrated how robotics through play can succeed in transgressing from welfare technology to design and play technology. The article's core concepts pla(y)cemaking and transgression defines play as designerly enterprise. In the interdisciplinary developed framework the categories of modularity, moveability, ideation, problem-solving, openendedness, and emergence are placeholders for concrete design- and learning-potentials in children's playful interactions with robotics together with categories for constructive and reflective actions in the shape of the play cultural core question "What if...?" and the design thinking core question "How might we...?". The article draws the conclusion that meetings between children and robotics conceptualised as pla(y)cemaking scaffold and promote children's attainment of distributed democratic formation.

\section{Indledning}

Denne artikel undersøger dannelsespotentialet i børns kulturelle legepraksisser og teknologiske designhandlinger med brug af modulære robotteknologier ved at analysere empiri, der er fremkommet gennem et 
feltarbejde, som undersøger børnehavebørns brug af teknologien Modular Robotic Tiles (MRTs), der er udviklet ved Center for Playware. Materialet viser, hvordan børnene er i stand til at konstruere deres egne steder, pla(y)ces, idet de anvender modulære teknologier som led i udøvelse af transformative og især transgressive design- og legepraksisser. Gennem kodificering og kategorisering af det analyserede materiale etableres et interdisciplinært begrebsligt rammeværk, der udpeger, hvordan robotteknologi som en særlig materialitet med en særlig struktur anvendes af institutionsbørn til at skabe egne (lege)rum for dannelse. Modular Robotic Tiles er oprindeligt designet som velfærdsteknologi til at skabe merværdi i fysiske trænings- og genoptræningssituationer, men i artiklen vises, hvordan de fungerer som kraftfuldt værktøj i børns legende designpraksis.

Kernebegrebet pla(y)ce betegner den stedsskabende proces, der emergerer ud af mødet mellem (legende) børn og (robot)teknologi. Begreberne for det transformative og transgressive knyttes til denne proces, idet fokus lægges på dannelsespotentialet $\mathrm{i}$ lege med MRTs. Til disse centrale begreber tilføjes en række underbegreber for, hvad der funktionelt set er på færde i børnenes konkrete lege.

Artiklen fremdrager således centrale mekanismer og relationer, hvorigennem et emergerende dannelsespotentiale manifesterer sig i mødet mellem materiale (robotfliser) og legende børn:

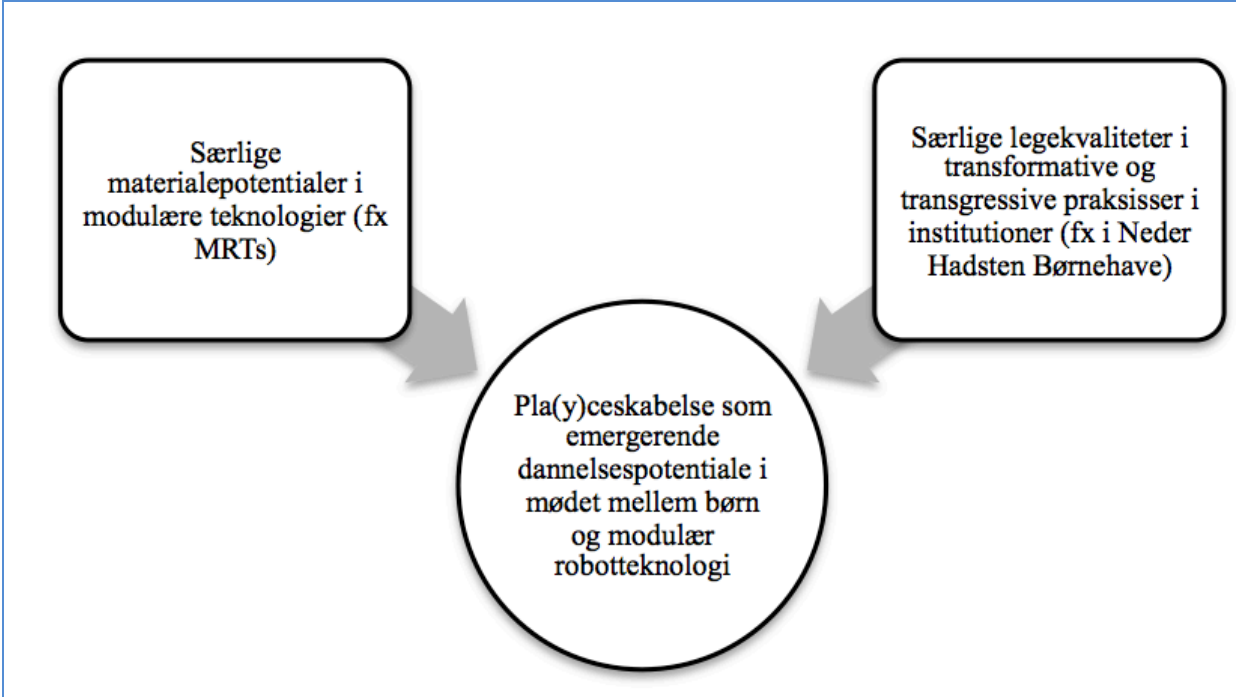

Figur 1. Pla(y)ceskabelse som emergerende dannelespotentiale.

Forfatterne har tidligere hver for sig udført studier af børns lege- og designhandlinger i daginstitutions- og skolesammenhænge baseret på Grounded Theory Method (Charmatz, 2006; Bryant og Charmatz, 2007; Brinkmann og Tanggaard, 2010). Under disse feltarbejder med indsamling 
af empiri gennem observationer (Gulløv og Højlund, 2003) har begge anlagt et børneperspektiv (Sommer, 2010; Gulløv, 2003:27-32; Kampmann, 2000) og ladet kodificering, kategorisering og teoretisering over børns leg ske på baggrund af konkrete iagttagelser og indsamlinger af deres faktiske leg.

Det ikke tidligere publicerede empiriske materiale for denne artikels teoretiseringer hidrører fra et feltarbejde, udført af Nørgård for Center for Playware ved Henrik Hautorp Lund og Carsten Jessen, og er udvalgt som eksemplarisk case. Artiklens forfattere har begge haft adgang til alle feltnoter og alt billedmateriale for at understøtte realiseringen af et interdisciplinært ståsted for analyse af designhandlinger med nye robotteknologier i børns legepraksisser. Analysen er altså foretaget med fælles metodisk tilgang, men samtidig med respekt for forskelle i forfatternes videnskabsteoretiske anknytninger.

Tofts tilgang baserer sig på legeteorier (Huizinga,1963; Caillois,1961; Sutton-Smith, 2001; Bateson, 2000; Gadamer, 1990; Sicart, 2014) og på kulturanalytiske studier af børns transformative og transgressive legekultur (Hastrup, 2004; Sørensen, 2008; Mouritsen, 1996; Mouritsen, 2003; Thestrup, 2013; Jessen, 2008; Jessen, 2013; Karoff, 2013; Dixon 2009; Toft, 2016). Toft henter hjælp i disse kilder for at begribe de særlige legekvaliteter og deraf følgende transformative og/eller transgressive improviserende legeinteraktioner, der viser sig i børnenes brug af robotteknologi i den valgte case. Nørgårds tilgang baserer sig på designtænkning (Nelson og Stolterman, 2012; Löwgren og Stolterman, 2004; Cross 2011; Schön, 1983; Edelson, 2002; Collins, Joseph og Bielaczyc, 2004) og på studier af teknologier som lege-, lære- og design-materiale (Lund og Marti, 2009; Lund, Klitbo og Jessen, 2005; Sullivan og Bers, 2015; Papert 1980; Resnick 1998; Resnick, 2007; Hornecker, 2007; Valk, Bekker og Eggen, 2013; Blikstein, 2013; Druin, 2010; Kaptelinin og Bannon, 2012; Schön og Bamberger, 1983; Nørgård, 2014; Nørgård og Aaen, 2015; Nørgård og Paaskesen, 2016; Nørgård, 2016). Nørgård henter hjælp i sine kilder for at begribe de særlige materialepotentialer, fabrikerede konstruktioner og deraf følgende idégenererende og problemløsende designinteraktioner, som i casen viser sig i børnenes møde med og brug af robotteknologi.

Det interdisciplinære ståsted for udvikling af et facetteret blik på børns møde med robotteknologi ses opstillet i nedenstående model: 


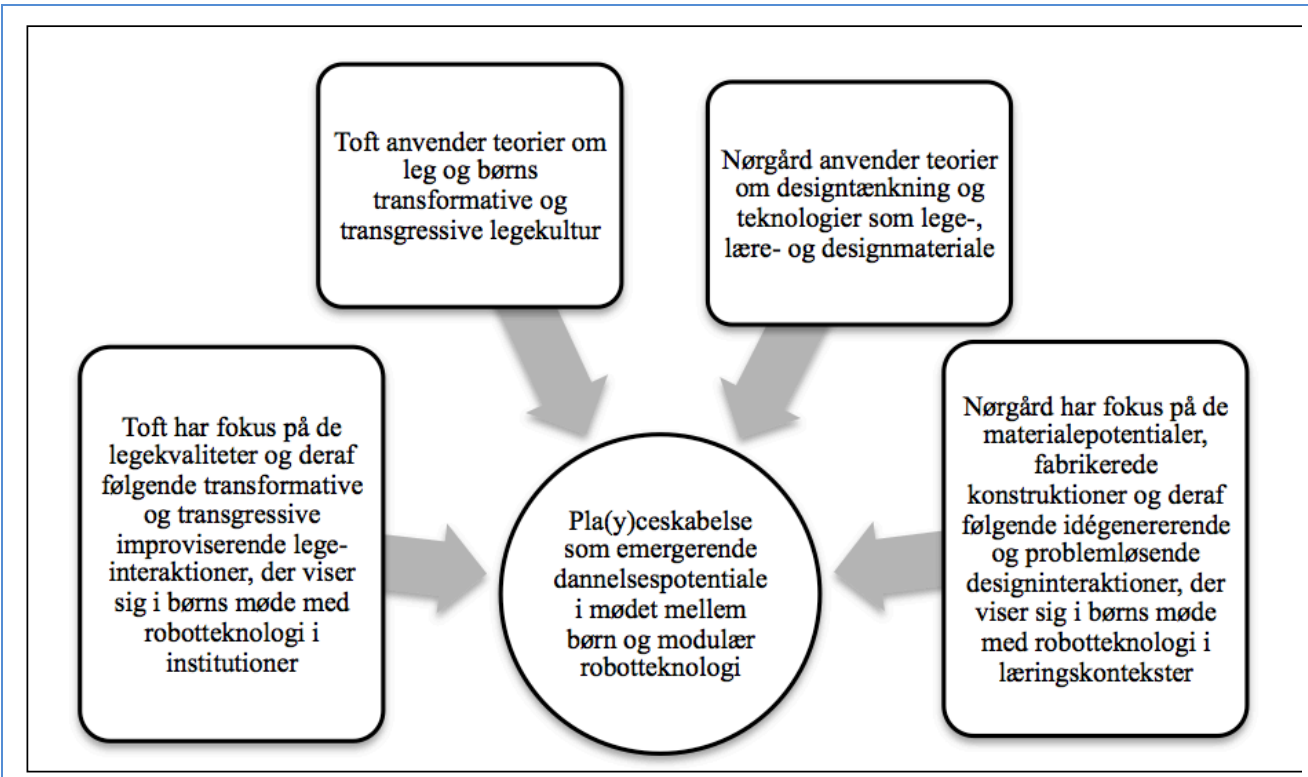

Figur 2. Interdisciplinære positioner og fokuspunkter.

Børn i møde med modulær robotteknologi er involveret i samme slags idégenererende og problemløsende designprocesser, som voksne designere er, hvorfor pla(y)ceskabelse kan ses som emergerende dannelsespotentiale (Vygotsky, 1993; Freire, 1974; Illeris, 2013; Rømer, 2010; Ranciere, 2007, Sicart, 2014; Nørgård, 2014; Nørgård, 2015). Artiklen konkluderer, at børn i leg hverken mentalt eller fysisk opererer indelukket i rammen af en 'magisk lege-cirkel' (Salen og Zimmerman, 2004) og dermed uden for samfundet (Sicart, 2014, Toft, 2016). De er tværtimod medskabende designere af og aktører i de praksisser og institutioner, de befinder sig i. Hvis altså de voksne tillader dem det. Argumentet for at tillade dem det er, at godt designet robotteknologi gennem legende designprocesser frigør et demokratisk dannelsespotentiale.

Artiklens argument falder i syv dele. Første del, "Modulær robotteknologi (MRTs)", præsenterer casens og analysens konkrete robotteknologi og indfører teknologi- og materialeperspektivet samt de materialepotentialer, der ligger i modulære robotteknologier. Anden del, "7 dages fortælling om børns møde med MRTs", præsenterer den valgte case og de centrale legeog designinteraktioner, der viser sig i børns møde med MRTs i en konkret børnehave over en periode på 7 dage, og danner det analytiske grundlag for tredje del, "Model for pla(y)ceskabelse", som præsenterer den fælles model. Fjerde og femte del, "Pla(y)ceskabelse" og "Transformative og transgressive interaktioner", redegør dels for begrebet pla(y)ceskabelse gennem stedteorier (place) og legeteorier (play), dels for teorier om transformative og transgressive interaktioner. I sjette del, "Dannelsesrelationer mellem børn og robotteknologi", udfoldes 
materialepotentialer, legekvaliteter og designtænkende træk i teknologien og i børnenes handle- og forestillingsrum. Det sker især gennem brug af kategorierne modularitet og flytbarhed, idégenerering og problemløsning, åbenhed og tilblivelse samt kategorier for konstruktions- og refleksionsspørgende handlinger. Endelig opsummerer konklusionen i den syvende del, hvordan godt designet robotteknologi gennem legende designprocesser kan frigøre dannelsespotentialet i børns pla(y)ceskabelse.

\section{Modulær robotteknologi (MRTs)}

En særlig form for modulær robotteknologi er interaktive fliser som fx Sony DataTiles, Z-Tiles, U-Texture, MEDIATE Wall, Twall, LightSpace og eksemplet i denne artikel, Modular Robotic Tiles (MRTs) (Lund og Marti 2009: 115). MRTs er udviklet af Center for Playware, Funen Hospital og Entertainment Robotics (www.google.com/patents/US8241183) for at motivere fx blodprop- eller hjertestopramte patienter til fysisk genoptræning eller fedmebekæmpelse gennem fysisk aktivitet (Lund, Klitbo og Jessen 2005:167). MRTs rummer særlige materialepotentialer, idet de, i modsætning til de fleste andre teknologiske fliser, ikke udgør en fast flade, men er modulære enheder, hvis layout ret enkelt kan om-konfigureres. MRTs er digitale, trykfølsomme kvadratiske fliser på 30 gange 30 centimeter med 8 farveskiftende dioder placeret bag en semitransparent plastikskærm. Kvadraterne er udformet som identiske puslespilsbrikker, der kan kobles sammen. I siderne er placeret infrarøde modtagere, så en flise kan kommunikere med tilstødende fliser (Lund og Thorsteinsson 2011:271-272). Hver spilleflise indeholder altså 8 lysdioder, der danner en cirkel, synlig under spilleflisens frostede plastoverflade. I cirklen er placeret en tryksensor, der aktiveres ved et nogenlunde præcist tryk af en vis styrke inden for cirklens omrids. Lysdioderne kunne i de tilgængelige spil i børnehaven skifte mellem farverne rød, grøn, blå, lilla og gul. De otte lysdioder kan være tændte eller slukkede. De digitale fliser interagerer med børnene gennem brug af farvecirkler på spillefliserne. I for eksempel "Colour Race" kan spilleren vinde ved at finde sin personlige farvecirkel ( $\mathrm{fx}$ rød) og trykke i alt 15 gange på den, efterhånden som den bevæger sig rundt på fliserne. I "Disco" skal spilleren holde øje med, at ingen af en flises lysdioder slukkes helt, for så tabes spillet. I "Udfald" skal spilleren hele tiden have ét ben placeret i den røde farvecirkel, mens der trykkes på de blå/grønne farvecirkler med det andet ben. I "Simon Says" skal spilleren memorere og korrekt gentage en forevist sekvens af farvecirkler på bestemte spillefliser.

Denne materialestruktur og -funktionalitet skulle betyde (Lund og Marti 2009: 116-117), at MRTs muliggør brugernes egne konstruktioner af gulvet samt valg mellem indkodning af forskellige spil gennem 'aktiveringsbrikker', der aktiverer spillene i den særlige 'spilstyrerflise.' Mulighed for rekonfiguration ses som central for modulære robotteknologier: "A paradigm of modular robotic systems is a distributed control system in which each module is self-processing for coordinated 
behavior. (...) The importance of a modular robotic system is emphasized on distributed control of each module and interacting capabilities between them in order for reconfigurable possibilities" (Ngo og Lund 2004, uden sidetal).

Det interaktive flisegulv samles som et gulvpuslespil og kan afspille forskellige spil, som spillere kan spille med og mod hinanden eller på egen hånd, når de interagerer med flisernes trykfølsomme plader og fortolker flisernes forskellige lyssymboler og deres betydning i et konkret spil. Der er ingen forkerte konstruktioner. Jo flere fliser, jo flere

konstruktionsmuligheder. I den nedenfor beskrevne feltarbejds-case havde fliseantallet en afgørende betydning for teknologiens mulighed for at understøtte emergerende lege- og designprocesser og fremkalde bestemte legekvaliteter. Børn kunne bygge både 2x4 flisegulve til fysisk motion og langstrakte labyrinter, der løb fra rum til rum, figurer, som lignede heste eller huse, ja baner, der fyldte hele det underliggende linoleumsgulv og dermed transformerede rummet ved at transgredere dets oprindelige funktion.

Artiklen videreudvikler tidligere arbejder med MRTs (Ngo og Lund, 2004; Lund, Klitbo, og Jessen, 2005; Lund og Marti, 2009; Lund og Thorsteinsson, 2011) ved specifikt at undersøge børnehavebørns møde med MRTs. Derudover nuancerer og udvider artiklen nyere centrale arbejder med robotteknologier til børn (Papert, 1980; Papert, 2000; Resnick, 1998; Resnick, 2007; Hornecker, 2007; Druin, 2010; Blikstein, 2013; Valk, Bekker og Eggen, 2013; Sullivan og Bers, 2015) ved at tilføre forskningen et humanistisk, legekulturelt perspektiv i stedet for at benytte et 'STEAM'perspektiv (Science, Technology, Engineering, Aesthetics og Mathematics). Det legekulturelle, 'nytte-løse' perspektiv er underrepræsenteret i studier af børn og robotteknologi, hvor interessen snarere samler sig om, hvad der produktivt set kommer $u d$ af legen end om, hvad der er på færde $i$ legen. Metodisk etableres perspektivet gennem en kombination af Grounded Theory Method, jfr. ovenfor, og Wild Theory, der er særlig egnet til at undersøge prototyper in situ: "A central part of designing in the wild is evaluating prototypes in situ. This involves observing and recording what people do and how this change over suitable periods of time." (Rogers, 2013: 58).

Det følgende er en kondenseret version af feltdagbogens notater og de fælles umiddelbare analyser af et sådant in situ-møde mellem børnehavebørn og robotteknologien MRTs. 


\section{7 dages fortælling om børns møde med MRTs}

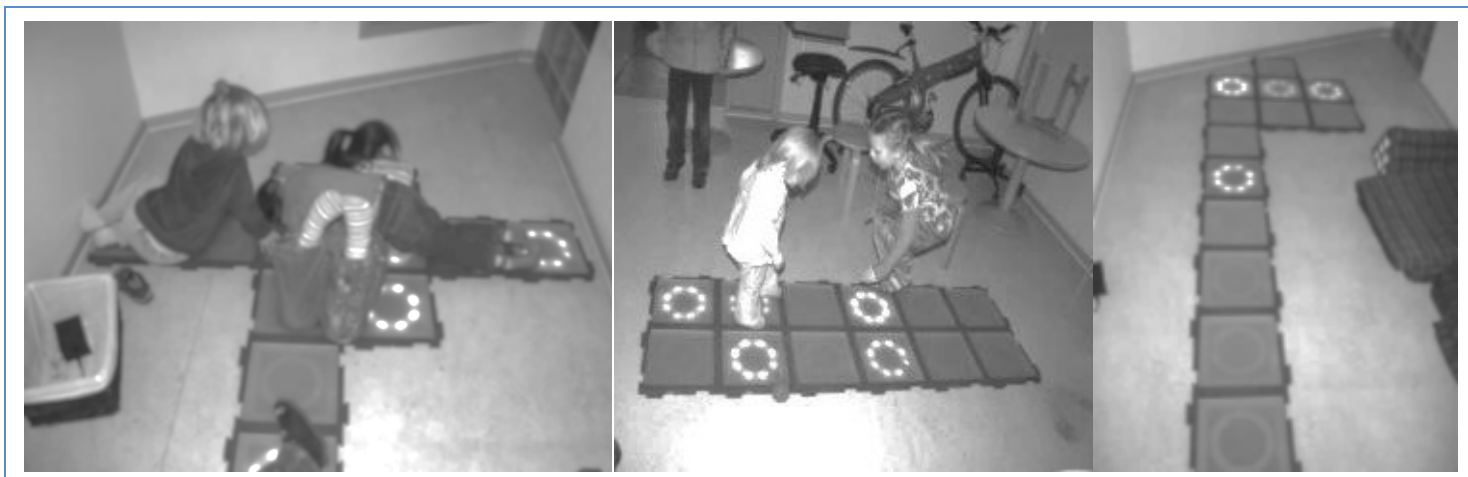

Figur 3. Leg med Modular Robotic Tiles (MRTs) i Neder Hadsten Børnehave.

Datamaterialet er indsamlet af Nørgård under et ugelangt feltarbejde i Neder Hadsten Børnehave og rummer billeder samt godt 50 sider med feltnoter om børnenes interaktioner med MRTs som led i en 6 måneder lang undersøgelse af legetøjs, legetings og legeredskabers rammesætning af leg og legende børn. Det samlede feltarbejde bestod af observationer i tre institutioner (to børnehaver og en skole), og observationerne involverede ca. 100 børn. I første omgang byggede Nørgård og pædagogerne flisegulve ved hjælp af medbragt spilstyrerflise, sender, fire spilaktiveringsbrikker med hver sit spil indkodet samt elleve spillefliser. Senere kreerede børnene selv.

På feltarbejdet første dag sammensætter feltarbejderen fliserne i et baneagtigt mønster på børnehavens gulv. En pige og en dreng hopper rundt på dem, mens de forsøger at ramme deres egen farve i spillet "Colour Race". Når alle fliser lyser op og blinker i vinderens farve, triumferer vinderen: "Yes!" og hæver stolt armene i vejret. Børnene er i en tilstand af tumult, optaget af jagten på deres personlige farve og fascineret af de flotte lys, der bevæger sig rundt på fliserne. Spillefliserne oplyser rummet med barnets 'personlige' lys og gør det kortvarigt til 'mit sted'.

I løbet af dagen etableres tre genkommende diskussionsemner blandt børnene: 1. Hvilken farve har jeg? Hvad betyder min farve for mig og mit sted? Kan man eje en farve? Og hvordan spiller min farve sammen med de oplevelser, interaktioner og steder, der skabes? 2. Hvilket gulv skal vi bygge? Hvordan fungerer vores gulv, og hvad er reglerne for det? Kan man eje et gulv? Og hvordan spiller gulvets struktur sammen med de oplevelser, interaktioner og steder, der skabes? 3. Hvilken leg skal vi lege? Kan man bestemme legen på et fælles gulv? Hvem ejer legen? Hvad er legens regler? Hvordan fungerer legen? Og hvordan spiller legen sammen med de oplevelser, interaktioner og steder, der skabes? 
Som svar på disse spørgsmål opstod fælles discodanse, magelige kattelege, drabelige sværdkampe, modeopvisning med publikum, regelbundne spilkonkurrencer og frie, fjollede frøhop.

På feltarbejdets anden dag har pædagogerne lagt fliserne ud, og legene kører. To store piger og en mindre dreng spiller koncentreret. Drengen spiller stille i rolig jagt efter den grønne farve. De store piger flyver rundt på banen og rundt om drengen i vild jagt efter deres lilla og blå cirkler i skarp konkurrence med hinanden. Andre børn sidder omkring og kigger på de lysende fliser og rundtomhoppende spillere: "Hvem tror du, der vinder?" spørger tilskuerne hinanden, og når banen lyser op i vinderens farve, udbryder de: "Flot!" og klapper i hænderne. En dreng rejser sig og tilbyder sin hjælp til den mindre dreng i kampen mod de store piger: "Er du grøn?" spørger den store dreng. "Ja," svarer den mindre dreng, "Skal jeg vinde for dig?", "Ja," siger den mindre dreng, og henvendt til de andre børn: "Se! Han vinder for mig!" De to drenge arbejder sammen om at være grøn i kampen mod lilla og blå pige.

Lidt senere brækker børnene fliserne fra hinanden og spreder dem over hele rummet. På den måde kan der være mange børn i samme rum, men på hver sit sted og på hver sin måde. "Disco"-fliser ligger spredt og blinker. Fire børn ligger i puderne og kigger på de blinkende lys. En pige står i hjørnet og spiller meget koncentreret "Udfald" efter reglerne. En dreng kommer til, stiller sig op på to sammenhængende "Disco"-fliser og danser en dans, men går væk kort efter: "Nej, jeg kan ikke mere! Jeg har for ondt i fødderne". En større pige kommer ind i rummet og begynder at spille "Udfald" på en smånynnende, balletagtig, snurrende måde, mens en dreng ved siden af spiller på en trampende, angribende, kontant måde. Børnene er i hver deres verden og alligevel sammen.

På feltarbejdets tredje dag spiller otte børn "Colour Race" på samme tid. Ved første øjekast ligner rummet et sted for tumult, rod og ustyrlighed mellem asende, masende kroppe. Men børnene danner små grupperinger, fordeler sig rundt på fliserne og trykker på gruppens farve, idet den dukker op på 'deres sted'. Børnene har selv kombineret fliserne og startet spillet. Endnu to små piger vil gerne være med og kaster sig ind i kampen: "Jeg er grøn, jeg er grøn!", "Det er mig, der er grøn!", "Jeg er lilla!", "Jeg er blå!" En mindre dreng støder til og begynder at hoppe ind og ud af fliserne på de røde cirkler, mens han messer: "Og dér! Og dér! Og dér!", hver gang han lander på en rød cirkel. To mindre drenge sidder og venter på, at der skal opstå en løbetunnel mellem de kæmpende børn. En spillende pige begynder at glide og skride rundt på fliserne. Første gang sker det ved et uheld, fordi hun har glatte strømpebukser på, men lynhurtigt bliver bevægelsen integreret $\mathrm{i}$ legen, og børn begynder at glide rundt på fliser med vilje, imens de hviner. 
På feltarbejdets fjerde dag spiller tre større drenge en voldsom omgang "Colour Race". De kæmper, skubber, skændes: "Det er ikke sjovt! Jeg sagde jeg var blå først!", "Jamen, jeg er hele tiden blå!", "Hold op! Du må ikke holde i mig". Deres spil er en kamp om at vinde bestemte farver, magtpositioner og placeringer på fliserne. Nogle piger sidder i puderne og kigger på de kæmpende drenge, mens de kommenterer deres spillestil: "Jeg gider ikke spille, når der er så mange drenge!", "Det er altså ikke sjovt, når du siger 'ka-ching! Jeg får ondt i ørerne!”. Drengene ignorerer pigerne og kæmper ufortrødent videre.

I løbet af de første fire dage opstår et mønster i børnenes bevæggrunde for at opsøge rummet og gøre det til deres sted:

Nogle børn søger rummet, når ingen andre har etableret deres sted på fliserne. Så har de mulighed for at konstruere deres eget sted ved at sammensætte og indkode fliser på egne måder.

Nogle søger rummet, når andre børn allerede har konstrueret et sted, så de får mulighed for at komme 'på besøg' i nye steder.

Nogle søger rummet i selskab med bestemte børn, så de får mulighed for sammen at konstruere et sted, der inkarnerer en fælles forestilling og fabrikation.

Nogle forlader rummet, hvis der er bestemte børn i gang med at konstruere steder, der ikke er rare for de andre at være i.

Børn kan gå længe og 'holde øje med rummet' og vente på den perfekte mulighed for at erobre deres sted.

På feltarbejdets femte dag slæber børn fliserne fra det lille tumlerum og ud i alrummet. I modsætning til det lukkede rum, fliserne hidtil har befundet sig i, lægges de nu i et stort åbent rum, der fungerer som samlested for børns lege som frøhopper, dansemus, trampetrold, listetyv, kattemor etc. En prinsesse tripper hen på den lilla farve og etablerer sit sted: stiller sig på flisen, drejer og nejer fra side til side; flisen aktiveres, farven slukkes. Hun tripper videre på jagt efter næste farvecirkel, hvor hun kan stille sig og svanse og svaje fra side til side: "Jeg danser! Jeg er Tornerose!" proklamerer hun stolt, før hun tripper over til næste lilla cirkel. Hun stiller sig forsigtigt med en fod på hver side af den og lader sin lange kjole falde ned. Nu er farven skjult under kjolen, mens der uafbrudt strømmer et eventyrligt lys ud under 'prinsessen'.

På feltarbejdets sjette dag er børnene blevet fortrolige med fliserne. De har ændret karakter fra nye og særlige til et materiale, børnene kan bruge til at konstruere steder med, når de får lyst og behov for det i deres leg. Tre piger leger baby og bevæger sig ud på fliserne, idet de veksler mellem at kravle rundt på dem, spille på dem og sove på dem. De sætter en fælles regel: hver 
gang et spil er slut, skal de kravlende babyer tage sig en lur ud fra ræsonnementet: "Den farve, man ligger på, er den, man er i spillet". De er babyer, der kravler, ligger stille, slår hænderne i fliserne, sover med hovedet på farvecirklen som deres hovedpude, ligger drømmende, oplyst af hver sin farve på hver sit sted.

På feltarbejdets syvende og sidste dag leger 3 mindre drenge i skøn harmoni på fliserne; de har god plads og ro til at lege krigsleg. De har flyttet fliserne og bygget et sted for sig selv. De hopper op i luften og ned på fliserne af fuld kraft med samlede ben, mens de råber: "Hi-jahr!", "Jaahh!", "Hu-mah!", "Dahr!", "Ja! Jeg vandt!", "Ti-harh!", "Yah-dah!", når de lander på lysene. En voksen stikker hovedet ind og spørger: "Er det hårdt?", "Ja!!!", "Mit hår er helt vådt!" råber drengene glade tilbage. De har konstrueret en aflang fliserække og indkodet den med spillet "Colour Race". De har lært sig, at de med denne flisekonstruktion og spilkode skaber et sted, hvor de kan være sammen i fællesskab, men med hver deres farve, hver deres kampzone.

Et flygtigt legested er skabt af mødet mellem fliser og børn. Et pla(y)ce.

\section{Model for pla(y)ceskabelse}

Den umiddelbare analyse af feltarbejdets centrale rum, praksisser, strukturer og kvaliteter er kodificeret og kategoriseret i nedenstående model for pla(y)ceskabelse, som også trækker på forfatternes interdisciplinære legekulturelle og designtænkende tilgang. Modellen udgør artiklens centrale teoretiske bidrag og består af fire lag, der skal indfange og begrebsliggøre dels modulære teknologiers struktur og funktionalitet i børns designhandlinger og legepraksisser, dels børns transformative og transgressive interaktioner og oplevelser med modulære teknologier i institutioner:

- Det interdisciplinære perspektiv: Den alleryderste ring, kaldet pla(y)ce-skabelse, afgrænser det interdisciplinære perspektiv, som forfatterne har udviklet på baggrund af datamaterialet, idet det indfanger artiklens dobbeltbevægelse mellem børns konstruktion af teknologiske steder og teknologiske steders konstruktion af børn. I denne yderste ring ligger altså det interdisciplinære perspektiv, der har fokus på de kvaliteter og relationer, der potentielt opstår ud af børns medskabende og omskabende interaktioner og oplevelser med modulære teknologier i institutioner.

- Den værdigenerende kraft: Den allerinderste kerne indeholder den centrale værdigenererende kraft med det iboende dannelsespotentiale, som det interdisciplinære perspektiv analyserede frem af feltarbejdet, nemlig ophobningen af sådanne transgressive legepraksisser og designhandlinger, som hverken producenter af MRTs eller børnehavepædagoger havde kunnet forudse. De særlige materialepotentialer og legekvaliteter i børns 
møde med modulære robotteknologier fremstår tydeligst, når børn gennem legepraksisser og designhandlinger transgrederer eller overskrider den institutionslogik, de er indlejrede i og derigennem medvirker til at transformere den.

- De særlige materialepotentialer: Den indre ring består af seks cirkler, som tilsammen udgør de særlige materialepotentialer i modulære robotteknologiers struktur og funktionalitet. Tilsammen udgør de seks cirkel-kategorier den grundlæggende organisering af børnenes improviserende og fabrikerende lege- og designinteraktioner. Kategorierne er modularitet, flytbarhed, idégenerering, problemløsning, åbenhed og tilblivelse.

- De særlige lege- og designkvaliteter: Den ydre ring har fire retningspile og fire signalflag, for indkodede kvaliteter i børns kulturelle legepraksisser og teknologiske designhandlinger med modulære robotteknologier. De fire pile kategoriserer oplevelser og interaktioner, hvorigennem kvaliteter træder frem $\mathrm{i}$ pla(y)ceskabende materialer, medier og teknologier, forestillende og fremstillende oplevelser, fabrikerende og improviserende interaktioner og pla(y)ceskabende børn. De fire flag signalerer kvalitative kendetegn ved transformative og transgressive processer og viser, hvordan dannelsespotentialet i børns kulturelle legepraksisser og teknologiske designhandlinger opstår gennem deres indkodede, spørgende hvad nu hvis...? og hvordan kan vi...? kombineret med deres vurderende refleksion-i-legehandlinger og refleksion-over-legehandlinger. 


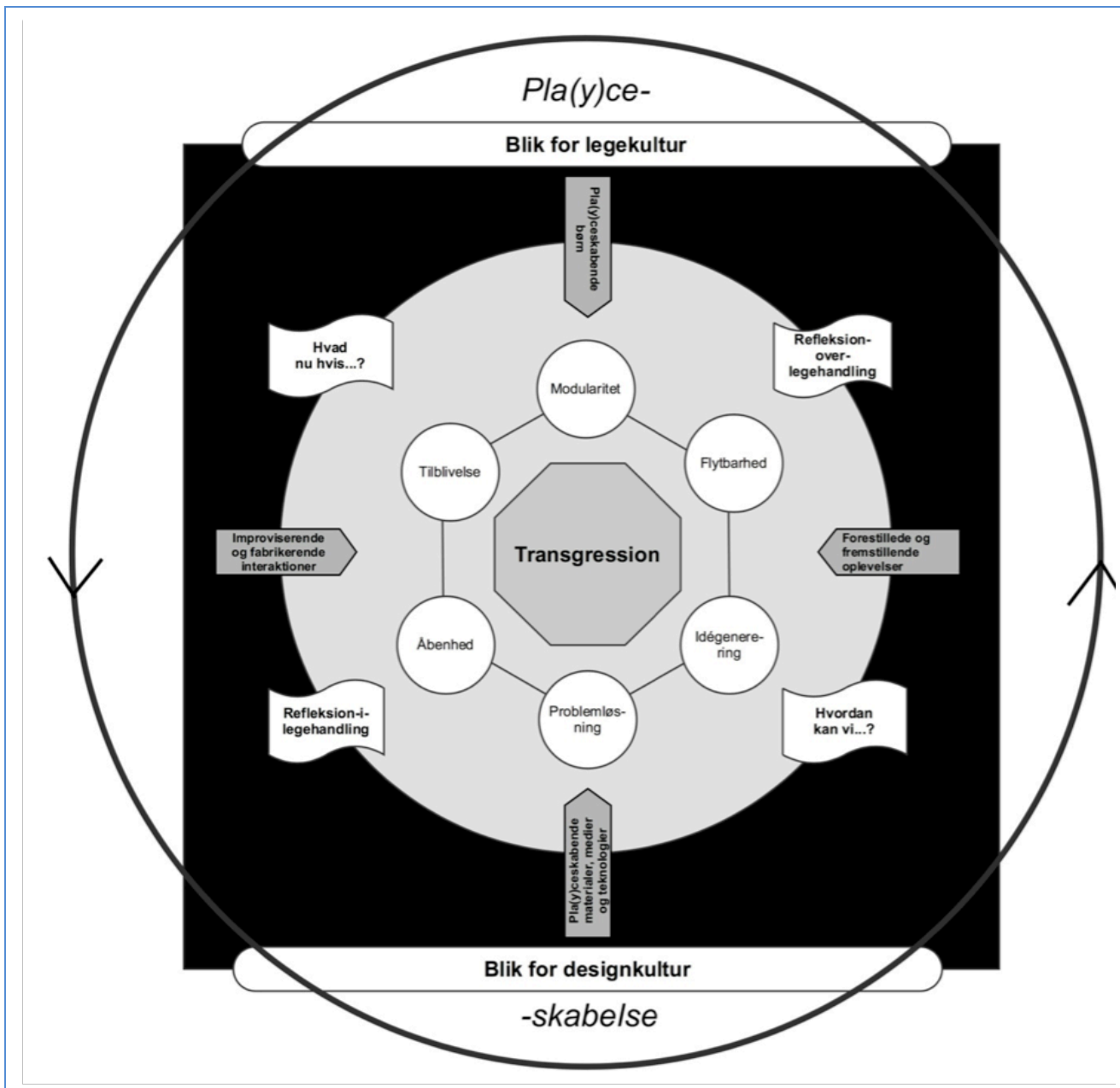

Figur 4. Model for pla(y)ceskabelse.

I det følgende udfoldes modellen kort, idet kategorierne efterhånden sættes i relation til centrale interaktioner og oplevelser i det feltarbejde, som danner baggrund for indkodningen.

\section{Pla(y)ce-skabelse}

Pla(y)ce er en sammensætning af begreberne play og place og betegner et 'place-to-play', dvs. ikke en fast forankret legeplads, men et flygtigt legested, konstrueret af børn gennem transformative og transgressive legeprocesser. Børnene skaber midlertidige steder for uformaliserede og uforudsigelige legebevægelser, (Toft, 2014: 33-36, jfr. desuden Rasmussen, 2006 og Clark, 2010). Begrebet pla(y)ce stammer oprindeligt fra spilforskeren Waltz (2010) i forbindelse med forskning i ludisk arkitektur i computerspil. Centralt hos Waltz er spillernes skabelse af egne steder gennem inddragelse af materialer, rum og hinanden. I herværende artikel videreudvikles begrebet om pla(y)ce (Toft, 2014; Toft, 2016a) til pla(y)ceskabelse, idet teknologiers rolle i steds-dannelse betones (Ciolfi, Fitzpatrick \& Bannon, 2007; Hornecker, 2007; Kaptelinin \& Bannon, 2012; Muller \& Druin, 2010; Nørgård \& Aaen, 2015; Nørgård, 2015; Nørgård 2016). 
Begrebet place (jfr. Nørgård \& Bengtsen, 2016; Gieryn, 2000; Tuan, 1977; Casey, 1997; Merleau-Ponty, 2002; Heidegger, 2001) kan i sig selv kvalificere forståelsen af de former for leg, der udøves i en vekslende dialektik mellem menneskelige og teknologiske aktører i et fælles rum.

Behovet for at udvikle begrebet om pla(y)ceskabelse opstod på baggrund af feltarbejdet, hvor børn kontinuerligt skabte, omskabte og genskabte steder gennem deres interaktioner og oplevelser med MRTs. Under 7 dages leg konstrueredes nye pla(y)ces: stillerum blev til spillerum, frokostrum blev til scenerum for dans og leg, idet børnehavens faste linoleumsgulv blev et 'flydende', modulært ombyggeligt gulv med skiftende legeflader / spillefliser.

Kulturgeografen Tuan skelner mellem gennemgangsrum og beboelsessteder ved at fremanalysere, hvordan rum fremtræder som koordinater og spatiale relationer, men er uden social forankring og betydning, hvorimod steder opstår gennem menneskelig betydningsskabelse og erfaringsdannelse (Tuan, 1977: 164-165). Steder er rum, hvori mennesker har indlejret værdier og betydning; steder træder ud af den abstrakte spatielle arkitektur og tager form som konkrete, beboelige og håndgribelige .

Filosoffen Casey (1997) nuancerer denne skelnen ved at betone rums arkitektur og teknologiers struktur og funktionalitet som medbestemmende for vores evne til stedsskabelse i det omfang, de rammesætter vores interaktion og oplevelse. Kan vi ikke ændre de rum og teknologier, vi lever i og med, må vi indordne os under dem (Casey, 1997: ix). Vores mulighed for at indrette egne leve-, lære- og væresteder har afgørende betydning for vores erfaringsdannelse og evne til at finde sted $\mathrm{i}$ verden (Merleau-Ponty, 2002, s. 161; Heidegger, 2001) samt vores mulighed for at bebo og lære i verden (Heidegger, 2001, s. 145-146).

Centralt for børns læring og dannelse bliver derfor, hvorvidt de føler sig velkomne i institutionsrummet og har mulighed for at skabe egne lære- og levesteder (Cresswell, 2004; Gieryn, 2000). I modsat fald kan de blive stedsløse: "To be without a place of one's own - persona non locata - is to be almost non-existent, as studies of the homeless imply" (Gieryn, 2000: 482).

Klassisk legeteori definerer individets legehandlinger som frivillige og selvregulerende i modsætning til dets (løn))arbejdshandlinger (Huizinga, 1963; Caillois 1961; Sutton-Smith, 2001; Mouritsen 1996, se desuden Salen og Zimmerman, 2004; Bateson, 2000; Gadamer, 1990; Thestrup, 2013; Karoff, 2013). Denne modernistiske optik revideres i disse år bl.a. gennem at forstærke et socialt og kulturelt betonet deltagelsesperspektiv på leg (Rancière, 2013; Sicart, 2014; Toft, 2016; Toft, 2016a), som ser legen udfolde sig imellem en række aktører, nemlig legende børn, fysiske rum, materialer, medier og teknologier, der hver især sætter muligheder og 
begrænsninger for legens konkrete udfoldelse (Toft, 2016, se desuden Jessen, 2008; Jessen, 2013; Dixon, 2009). Dermed forbindes legeteori med en designorienteret interaktionsteori, der netop ser teknologier som strukturerende, idet de indeholder muligheder og begrænsninger for stedsskabelse (Muller 2010; Kaptelinin 2012). Modulære teknologier, medier og materialer er legekræfter, som fabrikerer vilkår for leg (Blikstein, 2013; Papert, 1980; Papert, 2000). Leg omfatter på én gang teknologier, man fordyber og fortaber sig $\mathrm{i}$, og handlerum, man udtrykker sig i. (Toft, 2014; Toft, 2016).

Aktører skaber altså ikke pla(y)ces frit og selvregulerende, men heller ikke ufrit og udefrastyret. I stedet beror fremkomsten af pla(y)ces på, at der sker en udveksling imellem og en realisering af de potentialer, der findes dels i legekulturelle individer og fællesskaber, dels i designede legematerialer og -teknologier (Nelson \& Stolterman, 2012; WalterHerrmann og Büching, 2013). Sådanne potentiale-udvekslinger sker i transformative og transgressive interaktioner.

\section{Transformative og transgressive interaktioner}

Begrebet transformation betegner, at der under overførsel (transmission) sker en omdannelse, som fx under oversættelse af en tekst fra ét sprog til et andet. Transgression betegner, at der snarere end oversættelse sker en overskridelse af grænser, fx i form af en 'lovovertrædelse' eller det regelbrud, de tre børnehavepiger, der leger 'babyer', begår, idet de går imod flisernes velfærdsteknologiske intentionalitet ved at ligge stille og 'sove' med hovedet på farvecirklen som deres 'hovedpude' (for yderligere begrebsudredning se fx Biesta, 2012; Biesta, 2013; Moss, 2014).

I en model kan forskelle og ligheder mellem trans-begreberne tegnes således:

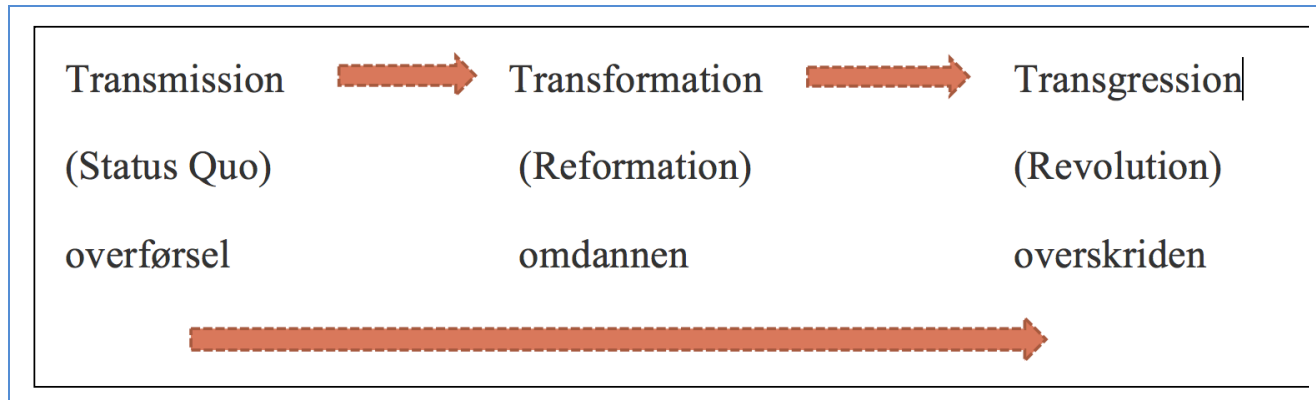

Figur 5. Model for transmission, transformation og transgression.

I et opgør med modernismens dualistiske erkendelsesmåde har fremtrædende teoretikere (fx Foucault, 2006 og Agamben, se hos Iversen, Nielsen og Ringgaard, 2003) peget på behovet for at ophæve fasttømrede, lukkede positioner ved at transgredere eller overskride erkendelsens og erfaringens afsnørede grænser for på den måde at etablere mulighedsrum 
for dynamiske, komplekse og flydende processer. I kritisk æstetisk designteori sammenstilles begreberne transgression og provokation. Gennem transgressivt design bryder man med etablerede sociale og kulturelle normer (Bardzell, 2012). I æstetisk teori bruges transgressionsbegrebet om avantgardekunst (Cresswell, 1996, Rice, 2014 og Architectural Humanities Research Association 2013). Lege- og læringsteoretikeren Bateson (Bateson, 2000) opererer med tre læringsniveauer: det at lære, det at lære at lære og det at lære at omlære. I denne artikel sidestilles det at lære at lære med transformativ læring, mens det at lære at omlære ses som transgressiv læring, idet den lærende må nedbryde resultater af tidligere gjort læring og transgredere eller overskride tidligere indøvede læringsstrategier, regelsæt og normer for at skabe nyt. Transgressionsbegrebet er dermed indfattet i et både kultur-, design-, æstetik-, lærings- og legemæssigt blik, hvilket er vigtigt, eftersom det er gennem transgression, dannelsespotentialet i børns legepraksisser og teknologiske designhandlinger for alvor kan frigøres.

Der er mange eksempler på transformative læreprocesser i feltarbejdet, som fx når børnene bruger flisernes forudprogrammerede spil på varieret vis. Fokus er imidlertid lagt på de transgressive processer, da det er fælles for avanceret design, leg og kunst, at aktørerne snarere belønnes end straffes for at afprøve og eksperimentere med ikke hidtil sete konstruktioner. Dannelse frigjort gennem transgressive læreprocesser, har altså en stærkere samfundsudviklende karakter, end den blot og bart transmitterende eller transformerende har.

Begrebet transgression fastholder opmærksomheden på, at den legende i leg kan forestille og fremstille det faktisk umulige som muligt. I feltdagbogen stod noteret, hvordan hidtil usete regler for lege- og spilhandlinger opstår og forsvinder uafbrudt. Således transgrederer eller overskrider børnene i interaktion med de digitale fliser børnehavens eget design af stillerum, frokostrum og linoleumsgulve. Gennem legen overskrides også flisernes design som forprogrammerede genoptræningspil. Endelig overskrider børnene sig selv som børn, idet de performer som prinsesser, babyer, diskodansere, katte, krigere ...

Med et fokus på, hvordan der i legekultur konstrueres pla(y)ces på transgressive måder, fremhæves legens - og robotteknologiens samfundsudviklende potentialer. Når det påpeges, at mentale grænser, kulturelle normer og værdier bliver de- og nykonstrueret i leg, argumenteres der samtidig for, at børns dannelse til demokrati fremmes og distribueres gennem leg. (Toft, 2016a; Toft, 2016). Børn i (flise)leg får en viden om, at rum ikke nødvendigvis er statiske; ved hjælp af deres forestillingskraft, refleksions- og designevne kan de selv finde eg(n)et sted. De kan tage symbolsk ejerskab over fliserne, udveksle og forhandle sig frem - og udvikle nye kompetencer. 


\section{Dannelsesrelationer mellem børn og modulær robotteknologi}

Analysen af feltdagbogen udmøntede sig i opstilling af seks kategorier fremdraget gennem et fokus på modulære teknologiers grundlæggende organisering af børns konkrete designhandlinger og legepraksisser, nemlig modularitet, flytbarhed, idégenerering, problemløsning, åbenhed og tilblivelse. Disse kategorier er gengivet i figur 4 ovenfor som indlejret i modellens indre ring. Gennem lege- og designhandlinger med MRTs kan børnene opleve særlige 'interaktionmæssige robotkvaliteter', en særlig 'dynamisk gestalt': "To experience this process, users must enter it: they need to actively interact in order to conceive the 'dynamic gestalt' or feel of interactive products" (Hornecker ,2007, uden sidetal). Kategorierne er ikke nødvendigvis de eneste gyldige, idet forskellige robotteknologier inviterer til forskellige færdigheder, etablerer forskellige møder og har forskellige kvaliteter (Hornecker, 2007).

Som beskrevet ovenfor indeholder MRTs et potentiale for stedsskabelse og kropslige teknologiinteraktioner (jfr. også Lund, Klitbo og Jessen 2005: 167). De seks kategorier fra feltarbejdsanalysen har mange lighedstræk med tidligere analyser, hvor fx Lund og Marti, 2009 betoner: modularitet, fleksibilitet, rekonfiguration, kropslig interaktion, feedback, konstruktionistisk leg, brugerdreven interaktionsdesign samt inkluderende spil og lege. Hvor Lund og Marti, 2009 og Ngo og Lund, 2004 har fokus på teknologiens 'produktivitet,' dvs. den nytte, der kommer ud af interaktionen, såsom at mindske risikoen for fedme, fremme kropslig genoptræning og/eller inklusion, så er fokus i denne artikel i stedet lagt på teknologiens 'dannelsespotentiale,' dvs. hvilke praktikker, der er på færde undervejs $i$ interaktionen, såsom idégenerering, refleksive designhandlinger eller transformative og transgressive oplevelser. Teknologien får her værdi og mening, for så vidt den inviterer til og muliggør, at børn er stedsskabende aktører i og designere af de institutionspraksisser, de som børnehavebørn er indsatte i. Med et sådant blik ses de seks materiale-kategorier herunder som særligt produktive pardannelser:

\section{Modularitet \& flytbarhed}

MRTs modularitet/fleksibilitet og flytbarhed får central betydning for børnehavebørnenes improviserende legepraksisser, teknologiudforskende designinteraktioner og pla(y)ceskabelse. Flisegulve kan hurtigt og let opbygges og ombygges, hvad angår størrelsesmæssig udformning, sammensætning og placering. I en iterativ konstruktionsproces improviserer børnene sig frem til nye lege, og ud fra de nye legepraksisser designer de gulve, så stedet passer bedst muligt til den aktuelle legekultur. De konstruerer, dekonstruerer og rekonstruerer fliser i stadig nye kombinationer - som stor korsformet spilleflade for spillet Colour Race og katteleg, som 5 små spillefliser for Disco og øhop eller som en kvadratisk 
flade for kampe, danse og spillege. Flisernes flytbarhed tillader dannelse af flygtige flisegulve - i fællesrummet til en lang catwalk, i stillerummet til kattelege og kamparenaer eller langs en mur til balance og hoppelege.

Børns med- og omskabelse af rum i institutionen betyder, at rum nogle gange transformeres til steder på måder, der understøtter eller udvikler rummets oprindelige funktion - som når børnene bygger et meditativt lysterapigulv i stillerummet, lægger sig ned på det og slapper af som henslængte katte. Andre gange transgrederes rum på måder, der overskrider eller omstyrter rummets institutions-satte funktion - som når stillerum bliver til vilde kamparenaer eller motionsrum, eller når rummet for fællesspisning redesignes til modeshow, komplet med fliseskabt lysende catwalk, udklædte modeller og tilskuere på skamler.

I løbet af feltarbejdet bliver børnene således i stand til at udvide deres legerepertoire ved at udnytte teknologiens modulære og flytbare kvaliteter til at fabrikere egne steder, der kalder på bestemte lege- eller designinteraktioner. I legen opstår en slags symbiotisk samtale mellem rum, design og teknologi, idet teknologiens organisering, funktionalitet og struktur understøtter skabelsen af nye pla(y)ces i institutionen. Rum er ikke længere blot rum, gulve ikke længere blot gulve, men noget, børnene kan konstruere gennem modulære designs.

MRTs modularitet og flytbarhed skabte grobund for børnenes forestillinger om, at et hvilket som helst legedesign i sin grundform kan bestå af ombyttelige elementer, der kan sammensættes og flyttes rundt på stadig nye måder, indtil den ønskede interaktion og oplevelse kan finde sted.

\section{Idégenerering \& problemløsning}

Lund og Marti peger i deres analyse af MRTs bl.a. på funktionerne 'tangible interaction' og 'immediate feedback' (Lund \& Marti, 2009: 117). Som følge af den interdisciplinære tilgang i denne artikel rettes fokus snarere på vekselvirkningen mellem de legende børns divergente og konvergente tænkning under deres møde med modulære robotteknologier som MRTs, idet de skifter mellem at fă ideer til nye flise-lege og at løse problemer, der opstår og forhindrer en ønsket flise-leg.

Kompetence i problemløsning udvikles primært gennem børnenes arbejde med fejlfinding og fejlretning i forbindelse med ønskede flise-lege. De første dage er det voksne, der opbygger fliseflader og programmerer spil, men så tager børnene over. Ved at konstruere og programmere sig frem lærer de at placere spilstyrerflisen rigtigt, så det ønskede spil kan afvikles, og de lærer at undgå sådanne opsætninger af flisegulve, som får spillet til at gå ned. I løbet af ugen begynder børnene at udvise diagnosticerende og problemløsende adfærd, når gulvopsætninger eller farvede cirkler ikke fungerer. Flise for flise skiller de fladen ad og genstarter fliser for at se, om problemet skulle være løst. De finder spilstyrerflisen og genprogrammerer 
den med spilstyrerbrikken, de ombygger et flisegulv, så det i højere grad kan køre et spil problemfrit. Gennem konstruktion, fabrikation og programmering opbygger børnehavebørnene simple kognitive modeller af flisernes fysiske og digitale funktioner og strukturer, og de forklarer sig flisefladers generelle virkemåde og eventuelle mangel på konsistens. Idégenererende interaktioner kommer ligeledes til udtryk gennem børnenes legende og designende udforskninger af flisernes materialitet og spiltyper. I løbet af feltarbejdet går børnene fra at spille det forhåndenværende spil helt i overensstemmelse med reglerne over til at skifte mellem forskellige spil med forskellige regler for at ende med at udnytte flisernes opbygning og programmerede adfærd til i fællesskab at finde på transgressive regler for nye spil og lege.

Pla(y)ceskabelse hænger tæt sammen med børnehavebørnenes kompetence i at indgå i kropslige interaktioner med fliserne, afkode deres feedback og mestre materialets modularitet og flytbarhed.

\section{Åbenhed \& tilblivelse}

De sidste materialepotentialer i MRTs, som Lund og Marti, 2009 opregner, er konstruktionistisk leg og brugerdreven interaktionsdesign - i feltarbejdet set som kvaliteterne åbenhed og tilblivelse. Flisernes forholdsvis simple, modulære udformning, der skal forhindre fejlkonstruktioner, og flisefladernes forholdsvis store gulvstruktur skabte steder for mange samskabende børn. Det processuelle og uafsluttelige forøger legekvaliteten i børnenes møde med den modulære robotteknologi.

Legesteder er under konstant tilblivelse og undergår kontinuerligt sømløse skift, fx fra kattekurv til kamparena, fra discogulv til spilleflise, fra frøhopbane, til skøjtebane og over til gymnastiksal. Også børnene selv befinder sig under stadig tilblivelse fra én aktørstatus til en anden, mens de udforsker flisernes åbne design. Der sker en form for krydsbestøvende, gensidigt formgivende samvirke mellem børn og robotteknologi. Børn bliver flisetænkere, legedesignere og stedsskabere i kraft af teknologiens åbne, modellerbare struktur. MRTs struktur, funktionalitet og organisering kalder på fysisk aktivitet, legeopfindelser, spilinteraktion, designhandlinger, fliseprogrammering og åben pla(y)ceskabelse. Fliserne fungerer som allegoriske fortællesteder for drabelige gladiatorkampe, actionfigurleg med farvecirkler som borge, fitness-sted for flise-pumpning, meditationsrum med lysterapi og puder og eksperimentarium for indkodning, afkodning og genkodning af fliser og spil. Børnene tager flisernes lege- og designinvitationer til sig og er i konstant transformerende og transgrederende fluktuering mellem fri leg, regelfølgende spil, sveddryppende aktivitet, programmeringshandlinger, designfabrikationer og hyggelig afslapning. Børn og MRTs er aktører i hinandens åbne tilblivelse. 
Sammenlagt viser feltanalysen af MRTs, hvordan "seemingly simple and open-ended creativity toys were often the most fun, inferring that creativity tools should enable the creation of complex products with simple tools, and that systems should be open-ended and not constrain the user more than necessary" (Hornecker, 2007, uden sidetal). Teknologi er ikke blot noget, børn anvender, men også noget, de bygger, samtidig med at de opbygger kompetencer, bl.a. i at håndtere kompleksitet, få ideer, løse problemer og fabrikere egne designs, spil og lege. Pla(y)ceskabelse er i både teknologisk og æstetisk henseende en ekspressiv affære: "With some toys expressive behavior arose from an intense interplay between toy and player, making it impossible to distinguish between the expressivity of the toy and of the player" (Hornecker, 2007, uden sidetal).

Ekspressiv også fordi legende børn veksler mellem at agere performativt som designere, udøvere og publikum (Sutton-Smith, 2001; Mouritsen, 2003; Toft, 2014).

Idégenerering og problemløsning understøttes og fremmes af åbenhed og tilblivelse, idet "Open-ended play with interactive objects provides children with the freedom to construct their own rules, goals and meaning" (Valk, Bekker og Eggen, 2013: 92). Det er hverken fri legeinteraktion eller regelfølgende spilinteraktion, men snarere en tilblivelse af leg, spil og steder, der opstår: "Open-ended play somewhat restricts the children in their free play as it offers objects with design intentions. The challenge for openended play is to develop designs that are specific and easy to understand but also general enough to encourage imagination and creativity in how to use them" (Valk, Bekker og Eggen, 2013: 93).

Vekselvirkningen mellem rammesat og frisat interaktion gør MRTs til et funktionelt lege- og designredskab i børns praksisser i børnehaven. Interaktionen er mindre fri end i byggeleg med Legoklodser og mindre bundet end i et spil Subway Surfers på smartphone. Der er frirum for legende forestillinger og fremstillinger, men også rammer og system for dem. Det åbne design under tilblivelse balancerer mellem "directing play and emergent play" (Valk, Bekker og Eggen, 2013: 97) og muliggør, at børnehavebørnene bliver stadig mere kompetente problemløsere og idégeneratorer i arbejdet med legens og designets materialitet.

Feltarbejdsdagbogen viser en række eksempler på, hvad læringsteoretikeren Schön kalder 'reflective conversations with materials' (1983a) - en dialogisk, refleksiv interaktion mellem materiale og børn: "In the first, the makers talk back to the materials (re-shaping them); in the second, the materials talk back to the makers, re-shaping what the makers know about them" (Schön, 1983a: 70). Robotteknologi som MRTs inviterer børn til at 'gå meta' for derved refleksivt at udvikle deres viden om og handlinger med materialet. MRTs er en art programmérbar 'digital manipulative' (Resnick, 1998: 1), der inddrager børn som aktive deltagere 
og medskabere og kalder på en pluralistisk problemløsende og idégenerende tænken og handlen (Resnick,1998: 2-3). Børnene bevæger sig fra at se spillefliser og spil i et rigtigt-forkert-perspektiv til at anskue dem som mulighedsrum for multiple ideer, forslag og løsninger. Der opstår et kognitivt, mentalt rum med en transgressiv kraft indlejret i legens metaunivers, såfremt altså børnenes legekulturelle forestillinger og designtænkende fremstillinger kan samvirke (Mouritsen, 2003).

Gennem pla(y)ceskabelse fremkommer et skift i børnenes opfattelse af strukturer såsom gulve, klatretårne, stillerum - fra at se dem som prædeterminerede og uomskiftelige til at se dem som dynamisk foranderlige. Børnehavebørnenes design- og legepraksis minder om Horneckers (2007) designstuderende og Resnicks (1998) videnskabeligt undersøgende børn. De interagerer med robotteknologien og får derigennem indsigt $\mathrm{i}$, hvordan dens system fungerer og kan programmeres. "People don't get ideas; they make them" (Resnick, 1998: 3). De erobrer nye færdigheder og indsigter gennem en form for kombinatorisk designpraksis (Resnick, 1998, Resnick, 2007, Papert, 2000, Hornecker, 2007). De udvikler en særlig modulær konstruktionsfærdighed ved lige som Horneckers (2007) designstuderende at spørge: "Which constraints and limitations does the toy set (or the rules connected with it)? Is there repetition or are there unlimited variations? (interaction space)? Do you react to the toy or do you control it - or is it a game of give and take? (type of conversation)" (Hornecker, 2007, uden sidetal).

Konstellationen af ovennævnte virksomme kræfter er ikke nødvendigvis særegen for digitale fliser, men kan genfindes i fx Legoklodser og Minecraft-blokke. I interdisciplinær optik er det imidlertid ikke kræfter, som teknologier, medier og materialer virker igennem, men snarere kræfter, der virker i samspillet mellem disses design og de legende børns interaktioner. Pilene i modellens ydre ring for forestillende og fremstillende oplevelser og fabrikerende og improviserende interaktioner signalerer kompetence- og dannelsesperspektiver i samspillet mellem børn og robotteknologi. Samspillet fremkalder spørgsmål som fx: "Hvordan kan jeg skabe mit eget sted?", "Hvordan kan jeg skabe rum for den leg og den væren, jeg har brug for?" og "Hvilke interaktioner og oplevelser har jeg lyst til at designe for min væren og tilbliven her i børnehaven?". Med de sidste to pile i modellen, pla(y)ceskabende børn og pla(y)ceskabende materialer, medier og teknologier, fastholdes opmærksomheden på også non-humane aktørers rolle i børns kompetenceudvikling og dannelse.

Igennem leg og design udforsker børn verden, som den er, og som den også kunne være. De bruger deres forestillingsevne. De er optaget af æstetisk formgivning. Som ovenfor nævnt inviterer MRTs som lege- og designredskab til fabrikerende og improviserende interaktioner bl.a. gennem åbenhed og tilblivelse (Valk et al, 2013; Resnick, 1998; Resnick, 2007; Hornecker, 2007). De fremanalyserede processer genkendes i 
Resnicks (2007) model for kreativ tænkning, hvor "children imagine what they want to do, create a project based on their ideas, play with their creations, share their ideas and creations with others, reflect on their experiences - all of which lead them to imagine new ideas and new projects" (Resnick, 2007, s. 2). I idégenerende og problemløsende designprocesser opnås kompetence i at udvikle ideer og afprøve, hvor grænserne for dem går, teste alternativer, diskutere dem med andre, før de transgrederes og nye ideer eller løsninger bryder frem i den iterative designproces (Löwgren og Stolterman, 2004; Nelson, 2012; Resnick, 2007).

I modellens ydre ring ses fire flag, som har indkodet kategorierne refleksion-i-legehandlinger og refleksion-over-legehandlinger samt de spørgende hvad nu hvis...? og hvordan kan vi...? Flagene begrebsliggør børnehavebørnenes nysgerrigt undrende, både spontane og refleksive tilgang til MRTs og signalerer dermed positive kvaliteter i et demokratisk dannelsesperspektiv.

For at børn som medborgere skal kunne konstruere deres egne legesteder, pla(y)ces, må de opøve kompetencer i både fortællings- og teknologiinteraktioner. Det gør de ved at kombinere færdighedsbaseret viden med refleksion-i-legehandling og refleksion-over-legehandling (begreber vi har tilpasset efter Schön, 1983, jfr. desuden ovenfor, hvor han taler om reflective conversation with materials). Under feltarbejdet sås børnene indsamle en kombination af sproglig viden, praktisk kunnen og kropsliggjorte erfaringer til det legerepertoire, de skaber, udbygger og distribuerer i fællesskab. Gennem refleksion-i-legehandling overvejer de, hvilket katalogiseret repertoire af erfaringer fra tidligere, de kan trække på i nuværende situationer. Gennem refleksion-over-legehandling overvejer de desuden fremtidige handlemuligheder. Børnekulturforsker Mouritsen har tidligere udpeget den samme vekselvirkning mellem viden, kunnen og refleksion i sin analyse af refleksivitet i børns rollelege og fortællinger (Mouritsen, 2003).

Det kan umiddelbart synes, som om børn går ind i leg og lader sig 'ureflekteret opsluge', jfr. filosoffen Gadamer: "Alles Spielen ist ein Gespieltwerden", legen leger legeren (Gadamer, 1990:112). Denne opslugthed er imidlertid højst at finde som midlertidig i feltdagbogen, der indfanger de legendes stadige refleksioner i og over både deres egne og andres legehandlinger, ofte formuleret gennem forhandlinger, jfr. fx de tre genkommende diskussionsemner blandt børnene på fliselegens første dag. For Gadamer er fascinationskraften i leg baseret på, at legen gør sig til herre over legeren. I det interdisciplinære perspektiv skifter de legende imidlertid frem og tilbage mellem positionerne 'legen-er-herre-overlegeren' og 'legeren-er-herre-over-legen', eller 'designet-er-herre-overlegeren' og 'legeren-er-herre-over-designet'. Dermed bliver det muligt for børnene at udnytte legerepertoiret til nye variationer og improvisationer. De kan overskride, transgredere, tidligere praksis. Børnene positionerede 
sig på den digitale MRT-legeflade i interaktioner af improviserende og fabrikerende karakter, de positionerede sig på puder ved siden af fliserne som publikum, kommentatorer og reflekterende praktikere, og de bevægede sig atter ind på fliserne for at opleve eller gennemleve nye forestillinger om 'den gode leg'.

I et dannelsesperspektiv ses mødet mellem børn og MRTs som præget af 'tinkerability' - der blev 'rodet med rytmeboksen' og 'sammenflikket' nye kombinationer: "In designing Scratch, one of our key goals was 'tinkerability' - that is, we wanted to make it easy for children to playfully put together fragments of computer programs, try them out, take them apart, and recombine them [...] You can even add new blocks as the program is running, so it is easy to 'play with your code,' testing out new ideas incrementally and iteratively" (Resnick, 2007, s. 4).

Strukturelt set består en børnehave som bygning primært af fysiske rum med gulve, vægge, lofter, vinduer og døre. Den er planlagt, designet og konstrueret af voksne (Krogstad, Hansen, Høyland og Moser, 2012), oftest med fokus på funktionalitet og tryghed, på institutionaliseret overvågning og overskuelighed snarere end på opfindsomhed og ombyggeri (Toft 2014). Set i et pædagogisk eller pasningsorienteret perspektiv skal gulve fungere som stabile, slidstærke, rengøringsvenlige og ufarlige underlag.

Kulturanalytisk (Hastrup, 2004) og ud fra et børneperspektiv er børnehavegulvet et 'flydende gulv', der er 'framet' (Bateson, 1972, jfr. også Vygotsky, 1933) som legens dynamiske sted. Børnene kan transgredere bestemmelsen af både faste gulve og løse gulvfliser/motionsfliser, idet de fabrikerer skiftende lyslandskaber beregnet til dans, modeopvisning, babysenge... alt sammen under løbende forhandling: "Hvad nu, hvis vi siger, at gulvet er et hav, og cirklerne er øer?", "Eller hvad nu, hvis vi i stedet for leger politi og røvere, og de her cirkler er fangehuller i et fængsel?", "Hvordan kan vi så bygge en røverborg af de her fliser?" - "Så er jeg røver, og du er politi, der vil smide mig i fangehullet på den flise dér!"

Pla(y)ces skabes i leg og er kendetegnet ved flygtighed. Er børnene ikke 'røvere' og 'politi', ja så er cirklen i flisen heller ikke et 'fangehul'.

I det foregående er børn set som designorienterede legepraktikere (Hansen, 2013; Resnick, 2007), der lytter aktivt til hinanden og til teknologier, der 'taler tilbage'. De er børn, som får en idé i flise-leg, der udløser spørgsmål som: "Hvad nu, hvis vi var en familie af katte, der boede i et hus?" og: "Hvordan kan vi konstruere flisen, så det ligner, den er et hus med forskellige rum, og kode den så cirklerne bliver kattekurve?" De stiller legekulturtænkningens kernespørgsmål: "Hvad nu hvis...?" (Toft, 2014) og designtænkningens kernespørgsmål: "Hvordan kan vi...?” (Druin, 2010; Nelson, 2012; Valk, Bekker og Eggen, 2013). Transgressivitet i legepraksis opstår, når børnenes forestilling om 'noget andet' kan forbinde sig med 
deres fremstilling af 'noget andet', når deres refleksivitet og spontanitet kan fă tid og rum for faktisk udfoldelse - når deres kultur- og designorienterede legepraksis kan befrugte hinanden, som illustreret $\mathrm{i}$ nedenstående model:

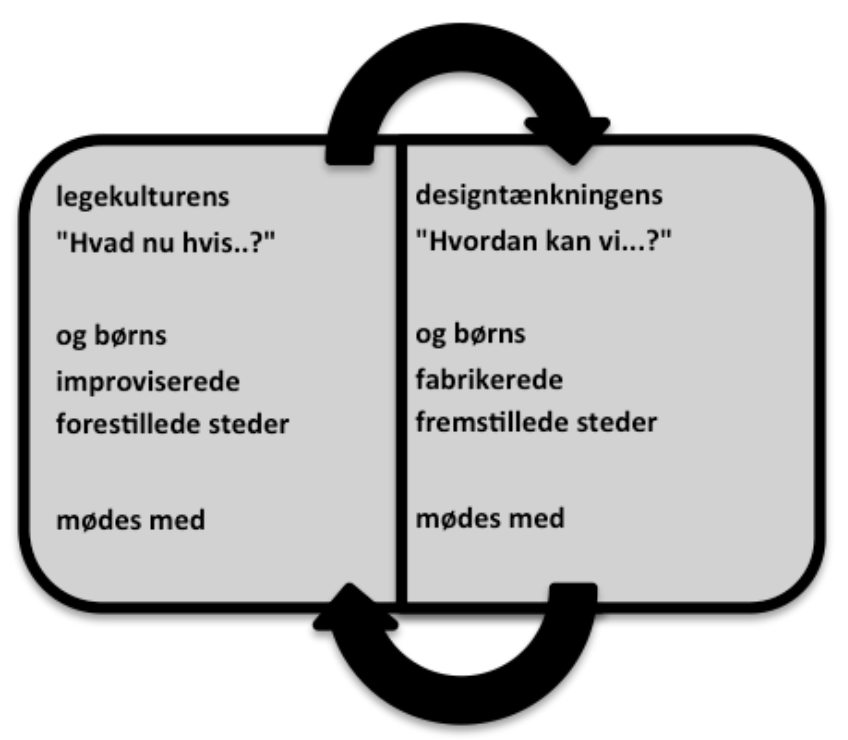

Figur 6. Børns kultur- og designorienterede legepraksis.

\section{Konklusion}

Analysen af legepraksisser som designhandlinger gennem brug af (robot-) teknologier tog Robotic Modular Tiles som eksempel og vurderede på baggrund af et feltarbejde, at robotteknologi kan medvirke til at realisere dannelsespotentialet i børns legepraksisser.

Børn konstruerer deres egne legesteder, dels gennem fortællingsinteraktioner, dels gennem teknologi-interaktioner. Deres forestillingsevne er tæt forbundet med deres fremstillingsevne, idet de samfører spørgsmålene "Hvad nu hvis (vi forestiller os)...?" og "Hvordan kan vi (fremstille)...?"

Begrebet pla(y)ceskabelse valgtes som betegnelse for dobbeltbevægelsen af legende børns konstruktion af 'steder' og af legesteders konstruktion af 'børn'. Gennem pla(y)ce-skabelse får børn mulighed for transgression, fordi pla(y)ces er æstetiske manifestationer, der ikke skal måles op imod en faktisk virkelighed. Børnene fastlægger betydninger flygtigt gennem en vekselvirkning mellem refleksion-i-legehandling og refleksion-overlegehandling.

Den praksisnære analyse af feltarbejdsdagbogen viste, hvordan børn i mødet med robotteknologi går virksomhedspræget og materialebevidst i gang med pla(y)ceskabelse, konkretiseret gennem teknologi- og færdighedskategorierne modularitet, flytbarhed, idégenerering, 
problemløsning, åbenhed og tilblivelse, i deres både transformative og transgressive legeprocesser.

Eksemplet MRTs viser en robotteknologi, der kan understøtte børns læreprocesser, både det transmitterende 'at lære', det transformerende 'at lære-at-lære' og ikke mindst det transgressive 'at omlære'. Børn bruger lege'tøj' som MRTs for 'omkostningsfrit' at kunne afprøve det ukontrollable, det uforudsete og det ubestemte. I et dannelsesperspektiv er der brug for sådanne 'digital manipulatives' (Resnick, 1998), der inviterer legende børn til at udfolde sig som deltagende designere.

Med dette dannelsesperspektiv kan begreber som socialisering og selvdannelse (Lars-Henrik Schmidt, 1999) ikke gribe børns faktiske dannelse gennem interaktioner med robotteknologi, eftersom de mange distribuerede humane og non-humane aktører på hver sin måde bidrager til dannelsen: robotteknologi er en aktør, det fysiske rum er en aktør, de andre børn er aktører ... legens oplevelses-, betydnings- og relationssystem for æstetiske læreprocesser er i sig selv at forstå som en aktør. Det valgte interdisciplinære ståsted peger på, at der sker en distribueret dannelse.

Tilbage står at undersøge, hvilken betydning det kan fă, dersom (børnehave)børn tillades kontrol over 'spilstyrerflisen', altså får mulighed for selvstændigt at kode deres lege- og spilaktiviteter. Dette sås (endnu) ikke realiseret i MRTs. Designere af robotteknologi må fremadrettet aktivt medtænke magt- og ejerskabsaspekterne, hvis de for alvor vil medvirke til at frigøre dannelsespotentialet i børns legekultur i demokratisk retning.

\section{Litteratur}

Aaen, J.H. \& Nørgård, R.T. (2015). Participatory Academic Communities: a transdisciplinary perspective on participation in education beyond the institution. In C.M. Restorff, C. Stage, J.L. Stephensen, L. Fabian, J. Fritsch, K. Samson \& T. Markussen (Eds.), Conjunctions. Transdisciplinary journal of cultural participation, Vol. 2, No. 2. Special issue on Participation Across, Between an Beyond Disciplines and Institutions, ss. 67-98.

Architectural Humanities Research Association.

Retrieved from www.ahra-architecture.org/

Bardzell, S., Bardzell, J., Zimmerman, J. \& Antanitis, J. (2012). Critical design and critical theory: the challenge of designing for provocation.

Proceedings from Designing Interactive Systems Conference, In the Wild, Newcastle, UK.

Retrieved from www.researchgate.net/publication/232251471.

Bateson, G. (2000) (1972). Steps to an ecology of mind. Chicago: The University of Chicago Press. 
Biesta, G. J. J. (2012). Doing Emancipation Differently: Transgression, Equality and the Politics of Learning. Civitas Educationis. Education, Politics and Culture, 1(1), ss.15-30.

Biesta, G. J. J. (2013). The Beautiful Risk of Education. Paradigm Publishers

Blikstein, P. (2013). Gears of our childhood: constructionist toolkits, robotics, and physical computing, past and future. Proceedings of the 12th International Conference on Interaction Design and Children. ACM: ss. 173-182.

Brinkmann, S. \& Tanggaard, L. (2010). Kvalitative metoder: en grundbog. København: Hans Reitzel.

Bryant, A. og Charmaz, K. (2007). The SAGE Handbook of Grounded Theory. London: SAGE.

Caillois, R. (1961) (1958). Man, play and games. USA: The Free Press of Glencoe, Inc..

Casey, E.S. (1997). The Fate of Place - a Philosophical History, Berkeley: University of California Press.

Charmatz, K. (2006). Constructing Grounded Theory. London: SAGE.

Ciolfi, L., Fitzpatrick, G. \& Bannon, L. (2007). Settings for Collaboration: The role of place. Computer Supported Cooperative Work, 17: ss. 91-96.

Clark, A. (2010). Transforming children's spaces: children's and adults' participation in designing learning environments. London: Routledge.

Collins, A., Joseph, D. \& Bielaczyc, K. (2004). Design Research: Theoretical and Methodological Issues. Journal of the Learning Sciences, 13:1: ss. 1542 .

Cresswell, T. (1996). In place/out of place. Geography, ideology and transgression. Minneapolis: University of Minnesota Press.

Creswell, T. (2004). Place - a Short Introduction. Oxford: Blackwell Publishing Ltd.

Cross, N. (2011). Design Thinking: Understanding How Designers Think and Work. London: Bloomsbury.

Dixon, D. (2009). Nietzsche contra Caillois: Beyond Play and Games. Proceedings from the Philosophy of Computer Games Conference, University of Oslo (uden sidetal)

Druin, A. (2010). Children as codesigners of new technologies. New Directions for Youth Development, Vol. 128: ss. 35-43.

Edelson, D. C. (2002). Design Research: What We Learn When We Engage in Design. Journal of the Learning Sciences, 11:1: ss 105-121.

Foucault, M. (2006). Ordene og tingene. En arkæologi om humanvidenskaberne. København: Det lille Forlag. 
Freire, P. (1974). Education for Critical Consciousness. London: Bloomsbury.

Gadamer, H. G. (1990). Wahrheit und Methode. Grundzüge einer philosophischen hermeneutik. Gesammelte Werke, Bd. 1. Tübingen: J. C. B. Mohr (Paul Siebeck).

Gieryn, T.F. (2000). A Space for Place in Sociology. Annual Review of Sociology, 26, ss. 463-496.

Gulløv, E. \& Højlund, S. (Red.). (2003). Feltarbejde blandt børn. Metodologi og etik i etnografisk børneforskning. København: Gyldendal.

Hansen, E. I. K. \& Iversen, O. S. (2013). You are the real experts! Studying teenagers' motivation in participatory design. Proceedings of the 12 th International Conference on Interaction Design and Children. ACM: ss. 328-331.

Hastrup, K. (2004). Kultur - det fleksible fællesskab. Aarhus: Aarhus Universitetsforlag.

Heidegger, M. (2001). Poetry, Language, Thought. New York: HarperCollins Publishers.

Hornecker, E. (2007). Learning about interactivity from physical toys. Nordes: Nordic design research. Vol 2, uden sidetal.

Huizinga, J. (1963) (1938). Homo ludens. Om kulturens oprindelse i leg. København: Gyldendal.

Illeris, K. (2013). Transformativ læring og identitet. København: Samfundslitteratur.

Iversen, S., H. S. Nielsen og D. Ringgaard, red. (2003). Ophold - Giorgio Agambens litteraturfilosofi. København: Akademisk Forlag.

Jessen, C. (2008). New play culture and playware. I: B. Juncker (red): Det æstetiskes betydning i børns hverdagspraksis. BIN Norden 2008.

Jessen, C. (2013). Leg, digitale medier og legekulturens forandring. Leg gør os til mennesker. En antologi om legens betydning. FDF: Forlaget $55^{\circ}$ Nord.

Kampmann, J. (2000). Børn som informanter og børneperspektiv. Kampmann, J. \& Jørgensen, P. S., (Red.), Børn som informanter og børneperspektiv. København: Børnerådet.

Kaptelinin, V. \& Bannon, L. J. (2012). Interaction design beyond the product: creating technology-enhanced activity spaces. HumanComputer Interaction, 27: ss.277-309.

Karoff, H.S. (2013). Play practices and play moods. International journal of play. Vol 2., no 2.: ss. 76-86. 
Krogstad, A., Hansen, G. K., Høyland, K. \& Moser, T. (Red.) (2012). Rom for barnehage. Flerfaglige perspektiver på barnehagens fysiske miljø. Bergen: Fagbokforlaget.

Lund, H. H., Klitbo, T. og Jessen, C. (2005). Playware technology for physically activating play. Artificial Life and Robotics, vol. 9, no. 4: ss 165-174.

Lund, H. H. og Marti, P. (2009). Designing Modular Robotic Playware. Proceedings from 18th IEEE International Symposium on Robot and Human Interactive Communication, ss. 115-121 (http://ieexplore,ieee.org/xpl/mostRecentIssue,jsp?punumber $=530651$ 7) .

Lund, H.H. og Thorsteinsson, A. T. (2011). Adaptive Play in Physical Play. Proceedings of the 6th International Conference on Foundations of Digital Games (FDG '11). New York: ACM, ss. 271-273.

Löwgren, J. \& Stolterman, E. (2004). Thoughtful interaction design: a design perspective on information technology. Cambridge Massachusets: The MIT Press.

Merleau-Ponty, M. (2002). Phenomenology of Perception. London: Routledge.

Moss, P. (2014). Transformative Change and Real Utopias in Early Childhood Education: A story of democracy, experimentation and potentiality. London: Routledge.

Mouritsen, F. (1996). Legekultur. Essays om børnekultur, leg og fortælling. Odense: Odense Universitetsforlag.

Mouritsen, F. (2003). Æstetisk refleksivitet og refleksionstyper i børns former for narrative udtryk og leg - en analyse af rolleleg og fortælling. Gleerup, J. \& Wiedemann, F. (Red.). Pædagogisk forskning og udvikling. Odense: Syddansk Universitetsforlag.

Muller, M. \& Druin, A. (2010). Participatory design: the third space. Jacko, J. (Red.). The Human-Interaction Handbook. Hillsdale, NJ: Lawrence Erlbaum Associates.

Nelson, H.G. \& Stolterman, E. (2012). the design way. Cambridge Massachusets: The MIT Press.

Ngo, T.D. og Lund, H.H. (2004). Modular artefacts. Proceedings of Component-Oriented Approaches to Context-aware Computing (ECOOP 2004), Oslo, Norway, 14 June 2004 (uden sidetal).

Nørgård, R. T. (2014). Talking Tacitly. Activities and Experiences in Highly Interactive Media. Nordicom Review, Vol. 35, ss.. 219-237.

Nørgård, R. T. (2015). Educational Design Thinking: On overcoming present tensions between educators and designers in design processes with new technologies within educational settings. Conference paper from The 
Oxford Ethnography and Education Conference, Oxford University, 1921. September 2015, Oxford, United Kingdom.

Nørgård, R. T. (2016). Expressive and affectionate technologies and gameplay. In B. Perron \& F. Schröter (eds.) Games, Cognition, and Emotion. Essays in cognitive video game studies. McFarland \& Company, Inc. Under udgivelse.

Nørgård, R. T. og Paaskesen (2016). Open-ended education: How openended artifacts, approaches, and attitudes in education might foster playful technological imagination, enterprising, and participation. In forthcoming issue of C.M. Restorff, C. Stage, J.L. Stephensen, L. Fabian, J. Fritsch, K. Samson \& T. Markussen (Eds.), Conjunctions. Transdisciplinary journal of cultural participation, Vol. 3, No. 1. Special issue on Playful Participation.

Papert, S. (1980). Mindstorms: children, computers, and powerful ideas. New York: Basic Books.

Papert, S. (2000). What's the big idea? Toward a pedagogical theory of idea power. IBM Systems Journal, Vol. 39, No 3 \& 4: ss.720-729.

Rasmussen, K. red. (2006). Børns steder. Om børns egne steder og voksnes steder til børn. Værløse: Billesø \& Baltzer.

Rancière, J. (2007). Den uvidende lærer - fem lektioner i intellektuel emancipation. Århus: Forlaget Philosophia, Aarhus Universitet.

Rancière, J. (2013). Hadet til demokratiet. (2005 udg. af forlaget MØLLER) Danmark: øbog.

Resnick, M. (1998) Technologies for lifelong kindergarten. Educational Research \& Development. Vol 46, no 4: ss. 1-18.

Resnick, M. (2007). All I really need to know (about creative thinking) I learned (by studying how children learn) in kindergarten. Proceedings from ACM Creativity \& Cognition Conference. Washington DC, June 2007 (uden sidetal).

Rice, L. \& Littlefield, D. (2014). Transgression: towards an expanded field of architecture. London: Routledge.

Rogers, Y. (2011). Interaction design gone wild: striving for wild theory. Interactions 18(4): ss. 58-62.

Rømer, T. Aa. (2010). Uddannelse i spænding. Århus: Klim.

Salen, K. \& Zimmerman, E. (2004). Rules of play. Cambridge: MIT Press.

Schmidt, L-H. (1999). Diagnosis I. Filosoferende eksperimenter. København: Danmarks Pædagogiske Institut.

Schön, D.A. (1983). The reflective practitioner: how professionals think in action. Aldershot: Arena.

Schön, D. A., Bamberger, J. (1983). Learning as reflective conversation with 
materials: Notes from Work in Progress. Art Education vol. 6 No. 2: ss. 68-73.

Sicart, M. (2014). Play Matters. Cambridge: The MIT Press.

Sommer, D., Samuelsson, I., P. \& Hundeide, K. (2010). Child perspectives and children's perspectives in theory and practice. London/New York: Springer Science. Part I.

Sullivan, A. og M.U. Bers (2015) Robotics in the early classroom: learning outcomes from an 8 week robotics curriculum in pre-kindergarten through second grade. International Journal of Technology and Design Education, vol. 25, no. 4: ss. 1-18.

Sutton-Smith, B. (2001). The Ambiguity of Play. USA: Harvard University Press.

Sørensen, A. S., Høystad, O. M., Bjurström, E. \& Vike, H. (2008). Nye kulturstudier. En innføring. Oslo: Spartacus Forlag AS.

Thestrup, K. (2013). Det eksperimenterende fællesskab - medieleg i en pædagogisk kontekst. Århus: Systime.

Toft, H. (2013). Den kultiverede leg - barnet mellem det dyriske og det dannede. S. Beck og D. Rüsselbæk Hansen (red.): Frihed og styring. En antologi om læringskulturer i forandring. Odense: Syddansk Universitetsforlag.

Toft, H. (2014). Lege-Rum og Fortælle-Tid - Kulturformidling i institutionelle rammer. Odense: Syddansk Universitetsforlag.

Toft, H. (2016). Leg som ustyrlig deltagelseskultur - eller fortællingen om det demokratiske æsel. Tidsskrift for børne- \& ungdomskultur nr. 61, Odense: Syddansk Universitetsforlag, under udgivelse.

Toft, H. (2016a). Børnekultur. F. B. Olsen (red.) Pædagogiske miljøer og aktiviteter. Grundfaglighed på pædagoguddannelsen. København: Frydenlund.

Tuan, Y-F. (1977). Space and Place. The Perspective of Experience. Minneapolis: The University of Minnesota Press.

Valk, L. de, Bekker, L. \& Eggen, B. (2013). Leaving room for improvisation: towards a design approach for open-ended play. Proceedings of the 12th International Conference on Interaction Design and Children (IDC '13): ss. 92-101. ACM, New York.

Vygotsky, L. (1933). Play and its role in the mental development of the child.

Retrieved from: www.marxists.org/archive/vygotsky/works/1933/play.htm.

Walter-Herrmann, J. and Büching, C. (eds.) (2013). FabLab: Of Machines, Makers and Inventors. Bielefeld: transcript Verlag. 
Waltz, S. P. (2010). Toward a ludic architecture: the space of play and games. ECT Press.

Retrieved from: www.etc.cmu.edu/ectpress/content/toward-ludicarchit.

www.google.com/patents/US8241183

www.playware.elektro.dtu.dk. 